\title{
A VP3/VP1 gene polymerase chain reaction assay for detection of chicken anemia virus in broiler samples
}

[Teste de reação em cadeia de polimerase dos genes VP3 e VP1 para detecção do vírus da anemia das galinhas em amostras de campo]

\author{
E.O. Nogueira ${ }^{1}$, L. Brentano ${ }^{2 *}$, A.J.P. Ferreira ${ }^{1}$ \\ ${ }^{1}$ Faculdade de Medicina Veterinária e Zootecnia - Universidade de São Paulo - São Paulo, SP \\ ${ }^{2}$ EMBRAPA Suínos e Aves \\ BR 153 km 110 - Vila Tamanduá - Caixa Postal 21 \\ 89700-000 - Concórdia, SC
}

\begin{abstract}
A PCR assay was designed for amplification of the highly conserved VP3 gene and a 5' region of the VP1 gene, for the diagnosis of CAV in organ samples of broiler flocks suspected of chicken infectious anemia. A comparison of the VP3/VP1 PCR with in vivo virus isolation revealed 100\% agreement of the results, with 13 positive and 3 negative samples in both assays, indicating that the VP3/VP1 PCR is a specific diagnostic method. Tissues from additional 24 broiler chicken flocks, with CAV-like lesions and clinical history were then tested only by the VP3/VP1 PCR and a reference PCR with published primers for the VP1 gene. Nineteen samples resulted positive and one negative in both PCR, while another 4 samples were positive only in the VP3/VP1 PCR. These results indicate that the VP3/VP1 PCR is a sensitive, specific diagnostic test, suitable as an alternative to the expensive and time consuming in vivo virus isolation method, specially considering the difficult diagnosis of CAV strains not readily adaptable to MSB-1 cell culture.
\end{abstract}

Keywords: chicken, chicken anemia virus, CAV, PCR, diagnostic test

\section{RESUMO}

Desenvolveu-se uma reação em cadeia de polimerase (PCR) para amplificação do altamente conservado gene VP3 e da região 5' do gene VP1, para o diagnóstico do vírus da anemia das galinhas (CAV), diretamente em amostras de campo de órgãos de frangos de corte com suspeita clínica da doença. A comparação entre o PCR VP3/VP1 com isolamento viral in vivo indicou $100 \%$ de concordância dos resultados, com 13 amostras positivas e três negativas em ambos os testes. Órgãos de outros 24 lotes de frangos com lesóes e história clínica compativel com CAV foram testados com o PCR VP3/VP1 e com um PCR de referência com primers conhecidos para o gene VP1. Dezenove amostras resultaram positivas e uma negativa em ambos os PCR $e$ quatro foram positivas apenas no PCR VP3/VP1. Estes resultados indicam que o PCR VP3/VP1 é um teste de diagnóstico sensível e específico, aplicável como alternativa ao método caro e demorado de isolamento viral in vivo e especialmente considerando-se amostras do CAV não adaptáveis a cultivos de células MSB-1.

Palavras-chave: frango de corte, vírus da anemia das galinhas, CAV, PCR, teste de diagnóstico

\section{INTRODUCTION}

Chicken anemia virus (CAV), isolated for the first time in Japan (Yuasa et al., 1979), causes aplastic anemia, generalized lymphoid organ atrophy and immunosuppression in young chickens (Goryo et al., 1987a; Yuasa et al., 1979). The disease has an important economic impact in chicken production, and a worldwide distribution (Von Bulow and
Schat, 1997). CAV is a non-enveloped, $25 \mathrm{~nm}$ icosahedral virus with a single-stranded circular DNA genome of $2.3 \mathrm{~Kb}$ (Gelderblom et al., 1989), classified as Gyrovirus in the Circoviridae family (Pringle, 1999). Other viruses in the family Circoviridae are porcine circovirus (PCV) (Ritchie et al., 1989) and psittacine beak-and-feather-disease virus (PBFDV) of the genus circovirus (Pringle, 1999). Replication of CAV occurs through a

Recebido para publicação em 6 de março de 2003

Recebido para publicação, após modificações, em 30 de junho de 2004

*Autor para correspondência (correspondig author)

E-mail: liana@cnpsa.embrapa.br 
dsDNA intermediate (Noteborn et al., 1991), encoding three proteins, VP1, VP2 and VP3, organized into three ORFs. ORF3 (1347 nt) encodes the $52 \mathrm{kDa}$ capsid protein VP1 (Noteborn et al., 1992a,b), ORF1 (648nt) encodes the 24kDa protein VP2 and overlaps with ORF2 (363nt) which encodes the $13.6 \mathrm{kDa}$ protein VP3 (Kato et al., 1995; Phenix et al., 1994).

CAV was first isolated in Brazil in 1990, from broiler chickens with thymus atrophy, anemia, poor flock performance, secondary bacterial infections and carcass hemorrhages (Brentano et al., 1991). Although the Marek's disease virus transformed chicken lymphoblastoid cell line, MDCC-MSB1 is permissive to CAV (Goryo et al., 1987b), Brazilian isolates of the virus and the American isolate CIA1, have not been readily adaptable to MDCC MSB1 cells (Lucio et al., 1990; Renshaw et al., 1996), what has hampered the diagnosis of CAV by virus isolation in cell culture. Therefore, the diagnosis of CAV infected chickens has required a method of in vivo isolation of the virus in SPF chickens that takes over two weeks and the use of strict special isolators, delaying the diagnosis and limiting the number of samples that could be processed. For this reason a polymerase chain reaction (PCR) assay was developed for the diagnosis of CAV in clinical samples of poultry flocks suspected of outbreaks of chicken infectious anemia. PCR is a powerful and extremely robust procedure for most applications and has been widely used for the diagnosis of several infectious diseases (Innis et al., 1990; Forbes, 2003; Relman, 2003). PCR has a major advantage of providing a faster and sensitive detection of more fastidious viral pathogens, that might require several days and consecutive passages in tissue culture for virus isolation, and allowing a fast in vitro diagnosis of viruses that may not be readily isolated in vitro in tissue culture, such as chicken anemia viruses identified in Brazil.

The validation and analysis of the specificity of the PCR, designed for the amplification of the highly conserved VP3 gene and a portion of the 5' region of VP1 gene, was determined by comparing the VP3/VP1 PCR with in vivo virus isolation in SPF chicks (Brentano et al., 1991) as well as with the results obtained with a previously reported PCR based on the amplification of a fragment of the VP1 gene (Todd et al., 1992). The aim of this work was to standardize and validate a PCR assay that could reliably replace the in vivo virus isolation assays and provide a more rapid, sensitive and specific diagnosis of CAV directly on field samples submitted to the laboratory for diagnosis of the disease in chickens.

\section{MATERIALS AND METHODS}

The Cux-1 strain (Von Bulow and Schat, 1997) was kindly provided by Dr. K.A. Schat (Cornell University, Ithaca - NY, USA), and was propagated in MDCC-MSB-1 cells. The Cux-1 virus was applied as a positive reference control virus for setting the optimal conditions for the PCR amplification of CAV. Eight reference Brazilian CAV positive isolates, originated from outbreaks of chicken infectious anemia in broiler flocks, were previously diagnosed as CAV by in vivo virus isolation (Brentano et al., 1991) between the years of 1990 and 1992, and were identified as CAV P15/90, P47/90, P159/90, P242/90, P245/90, P246/90, P247/90 and P91/92.

Additional 32 field sample tissues, which had been submitted to the laboratory for CAV diagnosis in the years 1998 and 2000, each originated from broiler chickens of 1 to 6 weeks of age, with a history of thymus atrophy, anemia, poor weight gain and overall poor production performance, from four Brazilian intensive poultry production states were employed. Samples identified as P91/98, P183/98, P91/99, P303/99, C821/98, P151/98, C520/98 and A420/98, were tested by in vivo virus isolation and PCR. The other 24 samples were tested only by PCR.

Field samples were identified as passage zero (P0) samples, and the tissues harvested at necropsy, from SPF chicks inoculated with P0 samples for virus isolations assays were identified as P1 samples, indicating the first virus passage in vivo.

For CAV isolation (P1) one-day-old specificpathogen-free (SPF) chickens were infected by intramuscular inoculation $(0.1 \mathrm{ml})$ of a $10 \%$ organ suspension (Brentano et al., 1991). At least 10 inoculated and 5 not inoculated (negative control) chicks were used for each field sample experimental infection, and maintained in positive pressure isolators. The chicks were examined for macroscopic lesions and hematocrit value determinations at 7 and 14 days post infection (DPI). CAV in vivo isolation was indicated by the development of CAV-like induced lesions, characterized by thymus atrophy, yellow to pink bone marrow, pale carcass, occasional presence of muscular hemorrhages and hematocrit values lower than $27 \%$. Fragments of thymus, liver and 
spleen were collected and stored at $-70^{\circ} \mathrm{C}$ for PCR and identified as passage 1 (P1).

Two DNA extraction methods were used throughout the experiments. One of the methods of DNA extraction from fragments of thymus and liver, and/or spleen was carried out by an adaptation of the procedure described by Boom et al., (1990). Two hundred microliters of a $10 \%$ organ suspension were added to $800 \mu$ l of lysis buffer $(120 \mathrm{~g}$ guanidinium isothiocyanate, $1 \mathrm{ml}$ Triton X-100 ${ }^{1}, 111.2 \mathrm{ml}$ Tris- $\mathrm{HCl} 0.1 \mathrm{M}$ pH 6,4 and $8.8 \mathrm{ml}$ EDTA $0.5 \mathrm{M} \mathrm{pH} 8$ ), $40 \mu \mathrm{l}$ of a $5 \%$ Diatomaceous Earth ${ }^{1}$ suspension, and $50 \mu \mathrm{HCl}$ $37 \%$ ). The sample was vortexed for $1 \mathrm{~min}$, and after $10 \mathrm{~min}$ precipitation at room temperature, it was centrifuged at $14.000 \mathrm{xg}$ for $90 \mathrm{sec}$. The supernatant was discarded and the pellet was washed twice by vortexing for $15 \mathrm{sec}$ with $500 \mu \mathrm{l}$ of washing buffer (120g guanidinium isothiocyanate, $100 \mathrm{ml}$ Tris- $\mathrm{HCl} 0.1 \mathrm{M} \mathrm{pH} 6.4$ ), then twice with $500 \mu \mathrm{l}$ of ethanol $70 \%$ ( $\mathrm{vol} / \mathrm{vol})$, and once with $500 \mu$ l acetone. At each wash the samples were centrifuged for 90 seconds at $14.000 \times \mathrm{xg}$ and the wash supernatant was discarded. After the acetone wash, the pellets were dried at $56^{\circ} \mathrm{C}, 100 \mu \mathrm{l}$ of TE buffer was added to the pellet, mixed, and incubated at $52^{\circ} \mathrm{C}$ for $10 \mathrm{~min}$. The vials were vortexed again and centrifuged for $5 \mathrm{~min}$ at $14.000 \mathrm{xg}$, and the supernatant containing the viral DNA was used for CAV DNA amplification.

The other DNA extraction method consisted of SDS/proteinase $\mathrm{K}^{2}$ and phenol-chloroform extractions of $10 \%$ suspensions of liver, thymus and/or spleen. The tissues suspensions were mixed with an equal volume of $2 \mathrm{X}$ lysis buffer $(200 \mathrm{mM} \mathrm{NaCl}, 100 \mathrm{mM}$ Tris $\mathrm{pH} 7.5,20 \mathrm{mM}$ EDTA, pH 8, $1 \%$ SDS) and $0.4 \mathrm{mg}$ of proteinase $\mathrm{K} / \mathrm{ml}$, incubated overnight at $37^{\circ} \mathrm{C}$ or $56^{\circ} \mathrm{C}$ for $2 \mathrm{~h}$, and treated 2 times, separately, with buffered phenol and with chloroform. Extracted DNA was precipitated in ethanol and $0.3 \mathrm{M}$ sodium acetate and resuspended in TE buffer $(10 \mathrm{mM}$ Tris, $\mathrm{pH}$ 7.5, $1 \mathrm{mM}$ EDTA, $\mathrm{pH} 8$ ).

The VP3/VP1 PCR was developed with a primer pair designed according to the sequence of the reference CAV Cux-1 isolate, obtained from Genbank, accession number M55918. The fragment amplified by primer pairs named VP3f

\footnotetext{
${ }^{1}$ Sigma Chemical Co., USA
}

${ }^{2}$ Gibco BRL, USA
5' GCG CAG GGG CAA GTA ATT 3' and VP1r 5' GTT CAC AGA GAT CTT GGC GAC T 3' flanked a region of 713 base pairs (bp), encompassing the coding gene of the viral protein VP3 and the N-terminal region of VP1 gene. The reverse primer was situated upstream of the hypervariable region of the VP1 coding gene. A second primer set, previously reported (Todd et al., 1992) here named Cav4a and Cav4b, was used as a reference for the results of the VP3/VP1 PCR. These primers amplify a 675bp DNA fragment encoding the N-terminal region of VP1.

Different DNA amplification conditions were initially tested with the reference Cux-1 virus and established as $50 \mu \mathrm{l}$ of a PCR mixture containing $1 \mathrm{X}$ Taq polymerase buffer $(50 \mathrm{mM}$ $\mathrm{KCl}, 1.5 \mathrm{mM} \mathrm{MgCl}_{2}, 10 \mathrm{mM}$ Tris- $\mathrm{HCl}, \mathrm{pH} 8.4$ ), 10 pmoles of each primer, $200 \mu \mathrm{M}$ of each $\mathrm{dNTP}^{3}$, 1U Taq DNA polymerase ${ }^{4}$. Samples were placed in a PTC-100 thermocycler ${ }^{5}$ and after an initial denaturation step at $94^{\circ} \mathrm{C}$ for $2 \mathrm{~min}$, the amplification was carried for 35 cycles of $94^{\circ} \mathrm{C} / 2 \mathrm{~min}, 50^{\circ} \mathrm{C} / 1 \mathrm{~min}, 72^{\circ} \mathrm{C} / 1 \mathrm{~min}$, followed by a final extension at $72^{\circ} \mathrm{C}$ for $3 \mathrm{~min}$. Twenty microliters of the amplified products were examined by electrophoresis on a $1 \%$ agarose gel stained with ethidium bromide $(1 \mu \mathrm{g} / \mathrm{ml})$, and visualized in an UV transilumminator. The amplification procedure adopted for the VP1 PCR with primer pairs CAV4a and CAV4b was as published (Todd et al., 1992).

DNA extracted from the reference strain Cux-1 cultured in MDCC MSB-1 cells, and from P1 organ suspensions of eight Brazilian isolates previously identified as CAV by virus isolation in vivo and monoclonal antibody testing of infected tissues, were used as CAV positive controls for the PCR. Also, these viruses were previously confirmed as CAV by DNA restriction analysis and by partial DNA sequencing of the VP3 and VP1 genes (Nogueira et al., 2000). Organ suspensions of CAVnegative SPF chicks were used as negative control DNA, and distilled Milli-Q ${ }^{6}{ }^{6}$ sterile water was used as negative control for every PCR amplification.

\footnotetext{
${ }^{3}$ Stratagene, LaJolla, CA, USA

${ }^{4}$ Gibco BRL, São Paulo, SP, Brazil

${ }^{5}$ MJ Research, Inc., Watertown, MA, USA

${ }^{6}$ Millipor Corporation, Bedford, MA, USA.
} 


\section{RESULTS}

The best PCR parameters for amplification of CAV DNA by the VP3/VP1 PCR were analyzed with the reference sample Cux-1 and with in vivo positive organ suspensions of Brazilian CAV isolates. Amplification in buffer containing $1.5 \mathrm{mM}$ or $2.0 \mathrm{mM} \mathrm{MgCl}_{2}$ were effective for amplification, and the primer annealing temperature at $50^{\circ} \mathrm{C}$ did not result in nonspecific products (Fig. 1 and 2).

Eight reference samples analyzed, and found positive by both PCR (Table 1), had already been diagnosed as CAV positive by virus isolation in the years 1990 to 1992 , as previously reported (Brentano et al., 1991). Besides the eight reference $\mathrm{CAV}$ in vivo isolates, another eight clinical samples, originated from field outbreaks of chicken infectious anemia in 1998 and 1999 were submitted to virus isolation in vivo during this work for validation of the PCR as a method for the diagnosis of CAV. Five of these eight field samples resulted positive for CAV by in vivo virus isolation in experimentally inoculated SPF chickens, with the reproduction of characteristic macroscopic lesions of $\mathrm{CAV}$ infection, and anemia as determined by hematocrit values lower than $27 \%$. Another two resulted negative, and one sample, P91/98, was regarded as suggestive positive for virus isolation since it resulted in the induction of a very discrete thymus atrophy, and anemia in less than $50 \%$ of the inoculated chicks. P9198 was only confirmed as positive by virus isolation upon a secondary passage (P2) of the P1 tissues in SPF chickens, after which it induced a severe macroscopic thymus atrophy, severe anemia and cellular depletion of the bone marrow, confirmed by histopathology (data not shown). Three samples (P151/98, C520/98 and A420/98) were considered negative in the in vivo virus isolation based on the lack of macroscopic lesions and normal, above $27 \%$, hematocrit values. None of the contact, control SPF chickens developed CAV lesions.
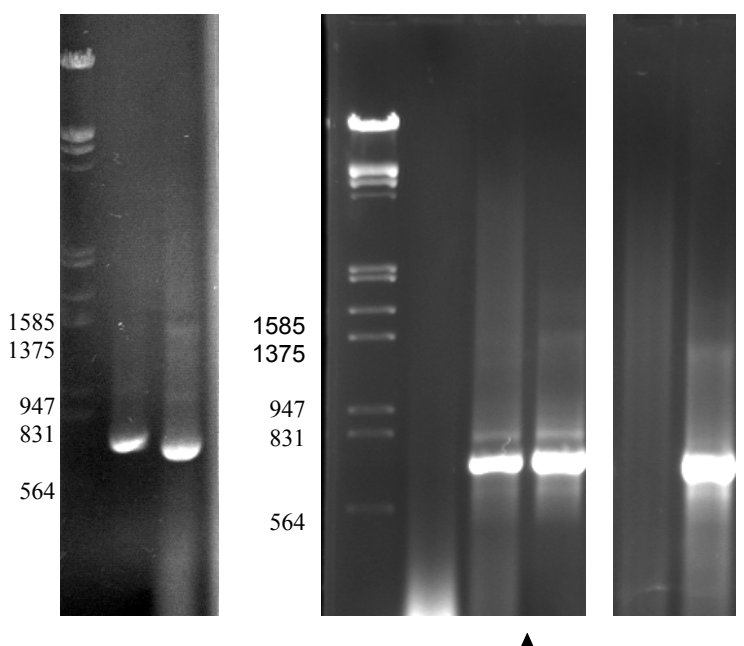

A
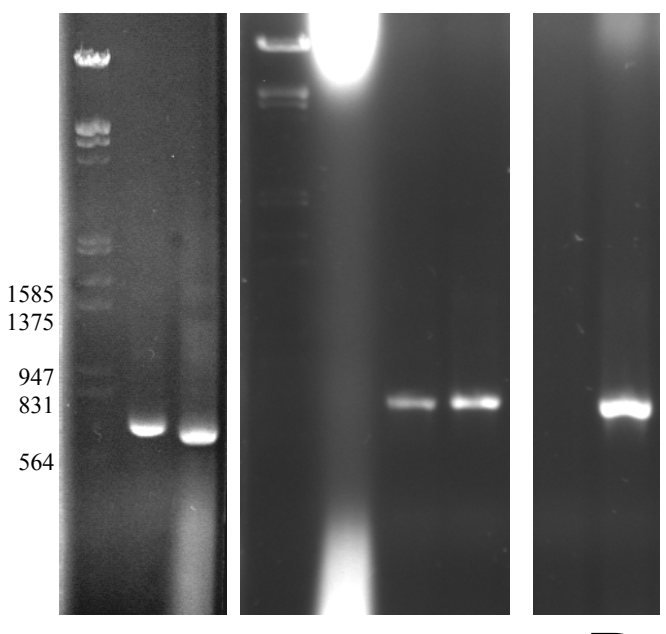

B

Figure 1. Illustration of the PCR results on representative field organ tissues (P0) and on organ tissues collected at 10 to 14 days post infection from inoculated SPF chickens from the in vivo virus isolation assays (P1). 1\% agarose gel elctrophoresis, stained with ethidium bromide. Panel A: VP1 PCR with primers CAV4a/Cav4b. Panel B: VP3 PCR with the designed VP3f/VP1r primers. $\lambda$ lambda DNA EcoRI/HindIII; lanes 1 P91/92 P0; lanes 2 P91/92 P1; lane 3 Negative control not inoculated SPF chicken; lanes 4 P47/90 P0; lanes 5 P47/90 P1; lanes 6 PP91/98 P0; lanes 7 P91/98 P1. 
A
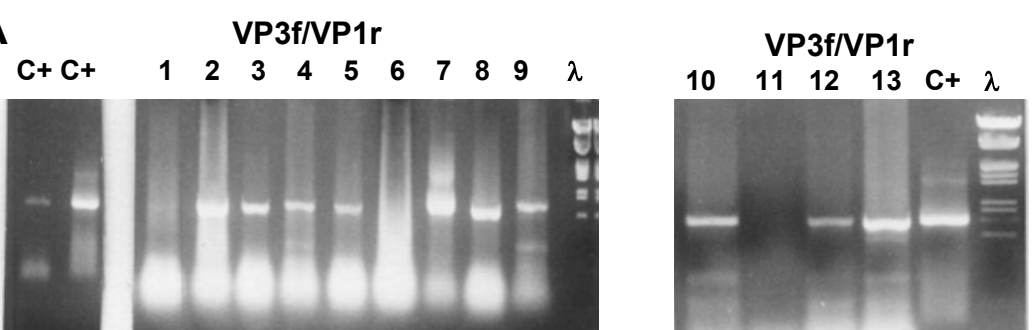

B

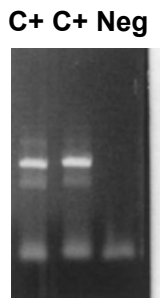

Cav4a/Cav4

$\begin{array}{llllllllllllll}1 & 2 & 3 & 4 & 5 & 6 & 7 & 8 & 9 & 10 & 11 & 12 & 13 & \lambda\end{array}$

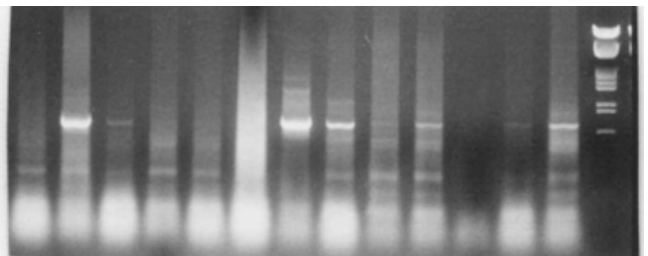

C I. Cav4a/Cav4b

II. VP3 f/VP1r
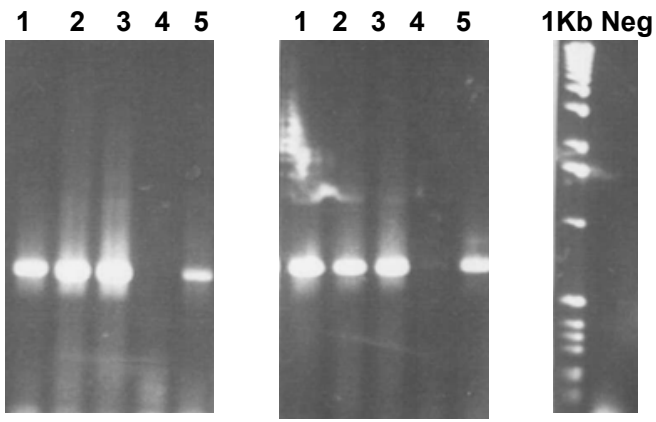

D I. Cav4a/Cav4b

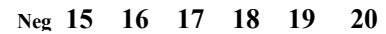

II. VP3 f/VP1r

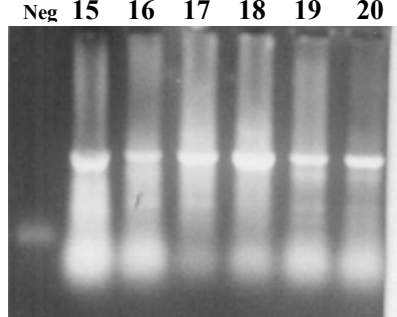

$\begin{array}{llllll}15 & 16 & 17 & 18 & 19 & 20\end{array}$

Figure 2. Comparison between the VP3 and VP1 PCR for direct detection of CAV in field organ tissues of broiler chickens. Each ID number identifies a different poultry flock and the year submitted for CAV diagnosis. Panel A: C+. positive control CAV P47/90; C+. positive control CAV Cux-1; lane 1. A1100/99; lane 2. A1108/99; lane 3. A1185/99; lane 4. A 1135/99; lane 5. A1136/99; lane 6. A1137/99; lane 7. A1139/99; lane 8. A1140/99; lane 9. A1141/99; lane $\lambda$. Lambda DNA EcoRI/HindIII (Sigma, USA); lane 10. A1142/99; lane 11. A1143/99; lane 12. A1144/99; lane 13. A1145/99. lane $\lambda$. Lambda DNA EcoRI/HindIII (sigma, USA). Panel B: VP1 PCR with primers Cav4a/Cav4b: C+. P47/90; C+. Cux-1; lane 2. A1100/99; lane 3. A1108/99; lane 4. A1185/99; lane 5. A 1135/99; lane 6. A1136/99; lane 7. A1137/99; lane 8. A1139/99; lane 9. A1140/99; lane 10. A1141/99; lane 11. A1142/99; lane 12.: A1143/99; lane 13. A1144/99; lane 14. A1145/99. lane $\lambda$. Lambda DNA EcoRI/HindIII (Sigma, USA). Panel C: I. VP1 PCR with primers Cav4a/Cav4b lane 1. Av109; lane 2. Av115; lane 3 Av116; lane 4. C597/00; lane 5. A1140/99. II. VP3 PCR with primers VP3f/VP1r. lane 1. Av109; lane 2. Av115; lane 3 Av116; lane 4. C597/00; lane 5. A1140/99. 1KB. 1 Kb DNA ladder (Invitrogen, USA); Neg. negative control. Panel D: I. VP1 PCR with primers Cav4a/Cav4b: lane 15. A1196/99; lane 16. A1197/99; lane 17. A060/00; lane 18. A062/00; lane 19 . A095/00; lane 20. A090/00; II. VP3 PCR with primers VP3f/VP1r: lane 15. A1196/99; lane 16. A1197/99; lane 17. A060/00; lane 18. A062/00; lane 19. A095/00; lane 20. A090/00. 
Table 1. Results of the VP3/VP1 PCR with primers VP3f/VP1r, in vivo virus isolation and a VP1 PCR* for diagnosis of $\mathrm{CAV}$ infection in broiler chickens

\begin{tabular}{|c|c|c|c|c|c|c|}
\hline & CAV sample & $\begin{array}{l}\text { In vivo virus } \\
\text { isolation }(\mathrm{P} 1)\end{array}$ & $\begin{array}{c}\text { VP3/VP1 PCR } \\
\text { (P0) }\end{array}$ & $\begin{array}{c}\text { VP3/VP1 PCR } \\
\text { (P1) }\end{array}$ & $\begin{array}{c}\text { VP1 PCR } \\
\text { (P0) }\end{array}$ & $\begin{array}{c}\text { VP1 PCR } \\
\text { (P1) }\end{array}$ \\
\hline 1 & P15/90 & + & + & + & + & + \\
\hline 2 & P47/90 & + & + & + & + & + \\
\hline 3 & P159/90 & + & + & + & + & + \\
\hline 4 & P242/90 & + & + & + & + & + \\
\hline 5 & P245/90 & + & + & + & + & + \\
\hline 6 & P246/90 & + & + & + & + & + \\
\hline 7 & P247/90 & + & + & + & + & NT \\
\hline 8 & P91/92 & + & + & + & + & + \\
\hline 9 & P91/98 & + & neg & + & neg & + \\
\hline 10 & P183/98 & + & + & + & + & + \\
\hline 11 & C821/98 & + & + & + & + & + \\
\hline 12 & P91/99 & + & + & + & + & + \\
\hline 13 & P303/99 & + & + & + & + & + \\
\hline 14 & P151/98 & neg & neg & neg & neg & neg \\
\hline 15 & C520/98 & neg & neg & neg & neg & neg \\
\hline 16 & A420/98 & neg & neg & neg & neg & neg \\
\hline
\end{tabular}

P0: Field organ sample; P1: organs (thymus and liver) harvested between 10 and 14 days post infection from virus isolation assay in vivo ( $1^{\text {st }}$ virus passage of P0 samples in SPF chicks). NT: not tested; +: positive; neg: negative.

*Todd et al., 1992

The specificity of the VP3/VP1 PCR, with primers VP3F and VP1R, was initially assessed using the reference strain Cux-1 and organ suspension from Brazilian isolates with previous passages in vivo in SPF chicks. The primer pair VP3F and VP1R amplified a 713 bp expected size fragment from CAV genome, in the absence of other nonspecific signals, as shown in Fig. 1, panel $\mathrm{B}$, lanes 2 and 3, for the CAV reference sample P47/90. The results for the Cux1 and P47 strains are demonstrated in Fig. 2, panel A, lanes $\mathrm{C}+$. CAV amplification was not detected in organ suspension from uninfected control SPF chicks (Fig. 1, lane 1). The reference VP1 PCR, with primer pair Cav4a and Cav4b amplified the expected size fragment of $675 \mathrm{bp}$, confirming the PCR results (Fig. 1, panel $\mathrm{C}$ lanes 2 and 3, and Fig. 2, Panel B, C+ P47/90 and Cux-1 strain).

For the validation of the PCR for the diagnosis of field outbreaks of chicken infectious anemia, the VP3/VP1 PCR was also compared to the results of in vivo virus isolation and to the reference VP1 PCR (Table 1). Organ suspensions collected at 7 to 14 DPI from SPF chickens inoculated for in vivo virus isolation ( $\mathrm{P} 1$ samples) were tested by the VP3/VP1 PCR with primers VP3f/VP1r and a VP1 PCR with primers Cav4a/Cav4b. The 13 in vivo virus isolation positive samples were found positive by both PCR assays on the P1 tissues collected at necropsy from SPF chickens inoculated with the P0 suspensions of pooled field organ tissues. The three field samples, P91/98, C520 and A420, determined as negative for virus isolation remained negative in both PCR. These results indicate a $100 \%$ agreement of the virus isolation assays with both VP3/VP1 and the VP1 PCR for detection of CAV in inoculated chickens (P1 tissues). The PCR assays were also evaluated for the detection of CAV directly on P0 field organ tissues which had not yet been submitted to virus isolation. Twelve of the thirteen field samples diagnosed as positive for $\mathrm{CAV}$ by in vivo virus isolation had the CAV genome detected in the P0 organ suspensions, and the three negative P0 samples, P91/98, C520/98 and A420/980, negative by virus isolation were also negative in both PCR. However, although the P0 sample 91/98 was found negative for CAV by PCR, the tissues collected from the P1 chicks with lack of clinical signs and thus diagnosed as negative by virus isolation were diagnosed as CAV positive by PCR. A second in vivo passage (P2) of sample P91/98 resulted positive for virus isolation and by PCR in the tissues from the P2 chicks (P2).

The additional 24 clinical samples, from broiler flocks from farms with a history of low performance and lymphoid organs atrophy in more recent years, not previously tested by in vivo virus isolation, were subjected only to PCR 
analyses, with primer pairs VP3f and VP1r (VP3/VP1 PCR) and Cav4a and Cav4b (VP1 PCR) (Table 2). Of the 24 P0 organ samples, 19 resulted positive (Table 2) and 1 negative in both PCRs. Four samples resulted weak positive only in the VP3 /VP1 PCR (Table 1, samples A1100/99, A1135/99, A1136/99, and C597/98).
The PCR reactions for most of these samples are illustrated in Fig. 2, Panels A and B in lanes 4 and 5 demonstrates the VP3/VP1 positive and the VP1 negative PCR results for samples A1135/99, A1136/99 respectively, and in panel C, lanes 4 for sample C597/98.

Table 2. Results of the VP3/VP1 PCR with primers VP3f/VP1r, and the VP1 PCR with primers $\mathrm{Cav} 4 \mathrm{a} / \mathrm{Cav} 4 \mathrm{~b}$ for direct diagnosis of CAV in field organ tissues from broiler chicken flocks with lesions suspected of chicken infectious anemia

\begin{tabular}{|c|c|c|c|}
\hline & CAV sample & VP3/VP1 PCR & Reference VP1 PCR (Todd et al., 1992) \\
\hline 1 & A1096/99 & + & + \\
\hline 2 & A1100/99 & Weak + & neg \\
\hline 3 & A1108/99 & + & + \\
\hline 4 & A1125/99 & + & + \\
\hline 5 & A1135/99 & + & neg \\
\hline 6 & A1136/99 & + & neg \\
\hline 7 & A1139/99 & + & + \\
\hline 8 & A1140/99 & + & + \\
\hline 9 & A1141/99 & + & + \\
\hline 10 & A1142/99 & + & + \\
\hline 11 & A1143/99 & neg & neg \\
\hline 12 & A1144/99 & + & + \\
\hline 13 & A1145/99 & + & + \\
\hline 14 & A1196/99 & + & + \\
\hline 15 & A1197/99 & + & + \\
\hline 16 & $\mathrm{~A} 060 / 00$ & + & + \\
\hline 17 & $\mathrm{~A} 062 / 00$ & + & + \\
\hline 18 & A090/00 & + & + \\
\hline 19 & A095/00 & + & + \\
\hline 20 & $\mathrm{~A} 087 / 00$ & + & + \\
\hline 21 & Av109/00 & + & + \\
\hline 22 & Av115/00 & + & + \\
\hline 23 & Av116/00 & + & + \\
\hline 24 & C597/98 & Weak + & neg \\
\hline \multicolumn{2}{|c|}{ Positive control Cux-1 virus } & + & + \\
\hline \multicolumn{2}{|c|}{ Negative control SPF chickens } & neg & Negative \\
\hline
\end{tabular}

\section{DISCUSSION}

A PCR test was developed for a rapid and specific diagnosis of CAV in chickens. The PCR primers were designed for amplification of the highly conserved VP3 gene and a 5' region of VP1 in order to attain the broad sensitivity of the assay for the purpose of diagnosis of CAV directly on field organ samples. In order to validate our VP3/VP1 PCR as an specific diagnostic tool, CAV field samples which had been tested for virus isolation in vivo, in SPF chickens, were submitted to PCR analysis with the VP3/VP1 PCR and to the already described VP1 PCR directed only to the VP1 gene of CAV (Todd et al., 1992) as a reference test. The comparison of the VP3/VP1 PCR results with the diagnosis of CAV by viral isolation in vivo demonstrated that all samples considered positive for CAV by virus isolation in vivo resulted positive by PCR, and all virus isolation negative samples resulted negative in the PCR, indicating an agreement in regard to the sensitivity and specificity of both methods for the diagnosis o CAV in organ samples. The specificity of the VP3/VP1 PCR was also confirmed by reproducible negative PCR results for DNA extracted from organs of SPF chickens, free of $\mathrm{CAV}$, and negative $\mathrm{PCR}$ results for negative control reactions without DNA, carried out in every test. 
The P0 field sample (Table 1; P91/98) which resulted only suggestive of CAV infection in the virus isolation resulted negative by both VP3/VP1 and the VP1 PCR on P0 but positive by PCR on P1 tissues, despite the very discrete lesions present in the first virus passage in vivo. The positive PCR result of P1 was confirmed as a specific result upon further passage $(\mathrm{P} 2)$ in SPF chickens, when characteristic CAV lesions were induced by sample P91/98. Therefore, both PCR detected the virus in the first passage in vivo (P1), whereas a second passage (P2) of sample P91/98 was required to confirm the diagnosis o $\mathrm{CAV}$ by in vivo virus isolation, indicating an expected better sensitivity of PCR assays as compared to virus isolation. Yet, the PCR was negative in the P0 P91/98 field sample, suggesting that both VP3/VP1 and the VP1 PCRs were not sensitive enough for samples which might carry a very low or degraded virus load, as indicated by the need of consecutive passages for CAV virus isolation. Compared to the other field samples analyzed, the lower sensitivity of both virus isolation and PCR for the P0 liver tissues of sample P91/98 could be a result of very low virus titer and thus insufficient virus yield for detection, or due to tissue autolysis, considering that this particular sample had been freeze-thawed and poorly refrigerated during transportation until arriving at the laboratory. When an organism dies, its DNA normally becomes degraded by endogenous nucleases or exogenous nucleases from bacterial contamination. DNA is particularly susceptible to degradation by hydrolytic and oxidative nucleases which, if not countered, break down DNA into small fragments of greatly reduced use for many assays. Under circumstances such as low temperatures, rapid desiccation, or high salt concentrations, nucleases activity are inhibited, and consequently DNA degradation is reduced (Dawson et al., 1998; Hofreiter et al., 2001). For this reason the removal of organs as aseptically as possible at necropsy to reduce bacterial contamination, and keeping tissues at lower temperatures, in order to inhibit the activity of bacterial or cellular proteases and nucleases, are important aspects in the submission of samples for laboratory analyses of nucleic acids and diagnosis of microbial pathogens (Dawson et al., 1998; Relman, 2003). Considering the effect of organ preservation on DNA integrity, it can not be ruled out that due to lack of proper handling the autolysis process might have released liver proteolytic enzymes and nucleases, with consequent lysis of the virus particles and DNA degradation, compromising the sensitivity of detection of CAV by virus isolation and PCR. A different DNA extraction protocol, based on SDS-proteinase $\mathrm{K}$ and phenol-chloroform extraction also showed negative results (data not shown), suggesting that the DNA extraction adopted was not a determinant of the negative PCR result of P0 sample P91/98. Todd et al. (1992) on their report of the VP1 PCR for diagnosis of CAV evaluated different methods of DNA extractions and determined that both a modified guanidinium isothiocyanate (Boom et al., 1990), and the SDS-proteinase $\mathrm{K}$ with phenol-chloroform, methods also applied in this work, were suitable for CAV DNA amplification from all positive samples tested, supporting the results obtained with the VP3/VP1PCR, that indicated as well that these methods of DNA extraction were effective for CAV diagnosis by the PCR in organ samples from broiler chickens suspected of chicken anemia. Although CAV has been detected by virus isolation in virtually every organ of infected chickens (Yuasa et al., 1983), the virus tropism for CD4 and CD8 T lymphocytes (Hu et al., 1993) makes the lymphoid tissues the major target organs for $\mathrm{CAV}$, and indeed, the thymus was described as containing more viral DNA than spleen or liver (Todd et al., 1991). Therefore, besides liver, the collection and submission of lymphoid organs, especially thymus, as well as spleen or bone marrow, should always be included in order to enhance the chances for a proper diagnosis of CAV by PCR.

Four of the additional 24 field samples, tested by PCR but not tested for virus isolation, resulted in a weakly positive result with the VP3/VP1 PCR, but negative in the VP1 PCR, suggesting a slightly better sensitivity of the VP3/VP1 PCR. It is not clear whether this represents a false negative reaction, or rather a specific reaction, considering the evidence for the adequate specificity of the VP3/VP1 PCR as indicated by the agreement of the PCR results with virus isolation tests, and by the reproducibility of the results for known positive and negative controls. Moreover, partial DNA sequencing and restriction analysis of 8 isolates of $\mathrm{CAV}$ (Nogueira et al., 2000; manuscript in preparation), confirmed the specificity of the 
amplification of CAV with the VP3/VP1 PCR primers.

While the VP1 PCR (Todd et al., 1992) was reported for the detection o CAV in MSB-1 infected cultures and SPF chickens experimentally inoculated with a controlled virus titer of the known reference CAV strain Cux-1, the VP3/VP1 PCR was evaluated, and compared to the VP1 PCR, for the specific detection of field virus both in SPF chickens experimentally inoculated with chicken organ samples of broilers suspected of CAV, as well as directly in the actual tissues (P0) submitted for diagnosis. Another PCR (Noteborn et al., 1992a,b) and a nested-PCR (Soiné et al., 1993) were also reported only for the detection of CAV in MSB-1 cell cultures infected with $\mathrm{CAV}$ rather than directly in chicken tissues from field cases suspected of CAV, and had already indicated as well that the PCR assay is highly sensitive for the diagnosis of CAV. The sensitivity of the nested-PCR from Soiné et al. (1993) was evaluated in regard to the amplification of cloned CAV DNA and could detect as little as one calculated virus genome equivalent, suggesting that the nested-PCR is an even more sensitive and thus more suitable test for CAV diagnosis than PCR. However, due to its sensitivity, the authors indicate that the nested-PCR is much more prone to cross contamination and therefore requires extreme caution in handling field samples and has to be carried preferably in separate facilities and equipment (Soiné et al., 1993), a matter that has to be even better observed when a nested-PCR is considered for routine use in diagnostic laboratories. Detection of CAV in chicken tissues such as thymus, spleen and livers, with primers directed to the VP3 gene, was also reported by Tham and Stanislawek (1992), who analyzed only seven field cases. Five samples were found positive by PCR and four were positive by virus isolation in tissue culture, indicating the better sensitivity of the PCR compared to virus isolation in tissue culture (Tham and Stanislawek, 1992). This is in contrast to the agreement found in this work between the two different PCR tested with virus isolation in vivo, suggesting perhaps that virus isolation in vivo provides a more sensitive test than virus isolation in vitro in MSB-1 cells, a relevant aspect even more when we take into account that the Brazilian CAV samples could not yet be adapted to propagation in tissue culture.

In conclusion, the analysis of natural outbreaks enabled the demonstration of an agreement between both PCR protocols and in vivo virus isolation and that, with the DNA extraction method and test parameters used, the VP3 and partial VP1 genes amplification PCR can be applied for a faster and specific diagnosis of CAV directly on field organ samples. The VP3/VP1 PCR is therefore a suitable diagnostic test, in substitution to the expensive and time consuming in vivo virus isolation method, formerly used to detect CAV isolates, such as the ones we have identified in Brazil, which are not readily adaptable to propagation in MSB-1 cells for in vitro virus isolation diagnosis.

\section{ACKNOWLEDGMENTS}

This work was supported in part by FUNCITEC/CNPq grant 520920/99-6, by FAPESP and Embrapa grant 06.1999.341-02 and is part of the Thesis requirements for fulfillment of the Masters Degree of Eliana O. Nogueira, University of São Paulo - USP, College of Veterinary Medicine.

\section{REFERENCES}

BOOM, R.; SOL, C.J.A.; SALIMANS, M.M.M. et al. Rapid and simple method for purification of nucleic acids. J. Clin. Microbiol., v.28, p.495-503, 1990.

BRENTANO, L.; MORES, N.; WENTZ, I. et al. Isolation and identification of chicken infectious anemia virus in Brazil. Avian Dis., v.35, p.793-800, 1991.

DAWSON, M.D.; RASKOFF, K.A.; JACOBS, D.K. Field preservation of marine invertebrate tissue for DNA analyses. Mol. Mar. Biol. Biotechnol., v.7, p.145-152, 1998.

FORBES, B.A. Introducing a molecular test into the clinical microbiology laboratory: development, evaluation, and validation. Arch. Pathol. Lab. Med., v127, p.1106-1111, 2003.

GELDERBLOM, H.; KLING, S.; LURZ, R. et al. Morphological characterization of chicken anemia agent (CAA). Arch. Virol., v.109, p.115-120, 1989.

GORYO, M.; SHIBATA, Y.; SUWA, T. et al. Outbreak of anemia associated with chicken anemia 
agent in young chicks. Jpn. J. Vet. Sci., v.49, p.867$873,1987 \mathrm{~b}$.

GORYO, M.; SUWA, T.; MATSUMOTO, S. et al. Serial propagation and purification of chicken anemia agent in MDCC-MSB1 cell line. Avian Pathol., v.16, p.149-163, 1987a.

HOFREITER, M.; SERRE, D.; POINAR, H.N. et al. Ancient DNA. Nature Rev. Gen., v.2, p.353-359, 2001.

HU, L.; LUCIO, B.; SCHAT, K. Depletion of CD4 and CD8 T lymphocyte subpopulations by CIA-1, a chicken infectious anemia virus. Avian Dis., v.37, p.492-500, 1993.

INNIS, M.A.; GELFAND, D.H.; SNINSKY, J.J. et al. PCR protocols: a guide to methods and applications. San Diego:Academic, 1990. p.325-385.

KATO, A.; FUJINO, M.; NAKAMURA, T. et al. Gene organization of chicken anemia virus. Virology, v.209, p.480-488, 1995.

LUCIO, B.A.; SCHAT, K.A.; SHIVAPRASAD, H.L. Identification of the chicken anemia agent, reproduction of the disease, and serological survey in the United States. Avian Dis., v.34, p.146-153, 1990

NOGUEIRA, E.O.; BRENTANO, L.; DURIGON, E.L. et al. Sequencing analysis of the N-terminal region of VP1 gene of Brazilian isolates of chicken anemia virus. Virus Rev. Res., v.5, supl., p.57, 2000.

NOTEBORN, M.H.M.; DE BOER, G.F.; ROOZELAAR, D. et al. Characterization of cloned chicken anemia virus DNA that contains all elements for the infectious replication cycle. J. Virol., v.65, p.3131-3139, 1991.

NOTEBORN, M.H.M.; KRANNENBURG, O.; ZANTEMA, A. et al. Transcription of the chicken anemia virus (CAV) genome and synthesis of its 52 Kd protein. Gene, v.118, p.267-271, 1992a.

NOTEBORN, M.H.M.; VERSCHEUREN, C.A.J.; VAN ROZEELAR, D.J. et al. Detection of chicken anemia virus by DNA hybridization and polymerase chain reaction. Avian Pathol., v.21, p.107-118, 1992 b.

PHENIX, K.V.; MEEHAN, B.M.; TODD, D. et al., Transcriptional analysis and genome expression of chicken anemia virus. J. Gen. Virol., v.75, p.905-909, 1994.
PRINGLE, C.R. Virus taxonomy. Arch. Virol., v.144, p.2065-2070, 1999.

RELMAN, D.A. Pathogen discovery, detection, and diagnostics. In: SMOLINSKI, M.S.; HAMBURG, M.A.; LEDERBERG, J. (Eds.). Microbial threats to health: emergence, detection, and response. Appendix C, Washington: The National Academies, 2003. p.313-330.

RENSHAW, R.W.; SOINÉ, C.; WEINKLE T. et al., A hypervariable region in VP1 of chicken infectious anemia virus mediates rate of spread and cell tropism in tissue culture. J. Virol., v.70, p.8872-8878, 1996

RITCHIE, B.W.; NIAGRO, F.D.; LUKERT, P.D. et al. Characterization of a new virus derived from cockatoos with psittacine beak and feather disease. Virology, v.171, p.83-88, 1989.

SOINÉ, C.; WATSON, K.; RYBICKI, E. et al. Determination of the detection limit of the polymerase chain reaction for chicken infectious anemia virus. Avian Dis., v.37, p.467-476, 1993.

THAM, K.M.; STANISLAWEK, W.L. Polymerase chain reaction amplification for direct detection of chicken anemia virus DNA in tissues and sera. Avian Dis., v.36, p.1000-1006, 1992.

TODD, D.; CREELAN, J.L., MCNULTY, S. Dot-blot hybridization assay for chicken anemia agent using a cloned DNA probe. J. Clin. Microbiol., v.29, p.933939, 1991.

TODD, D.; MAWHINNEY, K.A.; MCNULTY, S. Detection and differentiation of chicken anemia virus isolates by using the polymerase chain reaction. $J$. Clin. Microbiol., v.30, p.1661-1666, 1992.

VON BÜLOW, V.; SCHAT, K.A. Chicken infectious anemia. IN: CALNEK, B.W.; BARNES, H.J.; BEARD, C.W. et al. (Eds.). Diseases of poultry. 10.ed. Ames:Iowa State University, 1997. p.739-756.

YUASA, N.; NOGUCHI, T.; IMADA, T. et al. Distribution of chicken anemia agent (CAA) and detection of neutralizing antibody in chicks experimentally inoculated with CAA. Natl. Inst. Anim. Health Q. (Jpn), v.23, p.78-81, 1983.

YUASA, N.; TANIGUCHI, T.; YOSHIDA, I. Isolation and some characteristics of an agent inducing anemia in chicks. Avian Dis., v.23, p.366-385, 1979. 